Revista Brasileira de Farmacognosia Brazilian Journal of Pharmacognosy 22(3): 598-603, May/Jun. 2012

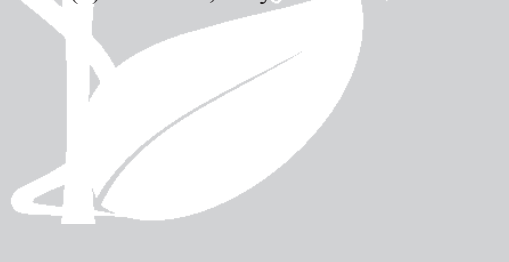

Article

Received 30 May 2011

Accepted 3 Oct 2011

Available online 9 Jan 2012

Keywords:

anti-inflammatory activity

antinociceptive activity

Maytenus rigida

Celastraceae

(-)-4'-methylepigallocatechin

ISSN 0102-695X

http://dx.doi.org/10.1590/S0102-

$695 \times 2012005000007$

\section{Antinociceptive effects of an extract, fraction and an isolated compound of the stem bark of Maytenus rigida}

\author{
Marina V. Martins, ${ }^{1,2}$ Charles dos S. Estevam, ${ }^{*, 3,4}$ André L. L. \\ M. Santos, ${ }^{4}$ Antonio S. Dias, ${ }^{4}$ Yolanda K. Cupertino-da-Silva, ${ }^{1}$ \\ João X. Araújo-Júnior, ${ }^{3,5}$ Ana Luisa P. Miranda, ${ }^{2}$ Eliezer J. \\ Barreiro, ${ }^{2}$ Cosimo Pizza, ${ }^{6}$ Sonia Piacente, ${ }^{6}$ Paola Montoro, ${ }^{6}$ \\ Lucindo J. Quintans-Júnior, ${ }^{7}$ Brancilene S. Araujo, ${ }^{4}$ Magna S. \\ Alexandre-Moreira, ${ }^{1}$ Antônio E.G. Sant'Ana ${ }^{3}$
}

\author{
${ }^{1}$ Laboratório de Farmacologia e Imunidade, Setor de Fisiologia e Farmacologia, \\ Instituto de Ciências Biológicas e da Saúde, Universidade Federal de Alagoas, \\ Brazil, \\ ${ }^{2}$ Laboratório de Avaliação e Sintese de Substâncias Bioativas, Universidade Federal \\ do Rio de Janeiro, Brazil, \\ ${ }^{3}$ Laboratório de Pesquisa em Recursos Naturais, Instituto de Química e \\ Biotecnologia, Universidade Federal de Alagoas, Brazil, \\ ${ }^{4}$ Laboratório de Bioquímica e Química de Produtos Naturais, Centro de Ciências \\ Biológicas e da Saúde, Universidade Federal de Sergipe, Brazil, \\ ${ }^{5}$ Escola de Enfermagem e Farmácia, Universidade Federal de Alagoas, Brazil, \\ ${ }^{6}$ Dipartimento di Scienze Farmaceutiche, Università Degli Studi di Salerno, Italy, \\ ${ }^{7}$ Laboratório de e Farmacologia Pré-clínica, Departamento de Fisiologia, \\ Universidade Federal de Sergipe, Brazil.
}

\begin{abstract}
The antinociceptive activity of the Maytenus rigida Mart. (Celastraceae) ethanol extract and its ethyl acetate fraction as well as of (-)-4'-methylepigallocatechin (1), a previously isolated compound, was demonstrated in vivo. ED50 for $\mathbf{1}$ in the writhing test was $14.14 \mathrm{mg} / \mathrm{kg}$. The acetic acid-induced writhing was inhibited by 98.4 , 84.4 , and $58.3 \%$, respectively, when mice were treated with the ethanol extract, ethyl acetate fraction, and $\mathbf{1}$. In the hot plate test, mice pretreated with $\mathbf{1}$ showed significantly increased reaction times (60-89\%). Oral administration of $\mathbf{1}$ significantly inhibited first and second phases of the formalin-induced pain (50 and 26.5\%, respectively), whereas indomethacin inhibited only the second phase of the test (41.2\%). Ethanol extract and its fraction showed effects on inflammatory pain, while neurogenic and inflammatory pain suppression by $\mathbf{1}$ is a strong indication of the presence of both central and peripheral effects and suggests its analgesic and anti-inflammatory potential.
\end{abstract}

\section{Introduction}

The enormous floral diversity of Brazil has provided local traditional health practitioners with an impressive array of plant material from which to select ingredients for use in herbal medicines. Over the centuries, this "natural pharmacy" has been developed and refined to treat many human and animal disorders. Even with the enormous technological advances that have been made in conventional modern medicine, nearly $70 \%$ of population in Brazil still relies heavily on traditional healing practices and phytomedicines for their daily healthcare needs (Begossi et al., 2002; Lima et al., 2006).
In a continued study aimed to establish scientific basis for the popular and ethnomedical uses of common Brazilian medicinal plants, we have investigated the pharmacological activities and chemical constituents of Maytenus rigida Mart., Celastraceae. Maytenus genus is widespread in Northeast of Brazil and its root, bark, and leaves are used in folk medicine to treat inflammation and pain (González et al., 2001; Mota \& Albuquerque, 2002; Fenner et al., 2006; Reyes et al., 2006; Sosa et al., 2007). Several classes of secondary metabolites are represented within the genus, including triterpenes (Shirota et al., 1996, Estevam et al., 2009), oligo-nicotinated sesquiterpenes and sesquiterpene pyridine alkaloids (Corsino et al., 1998), phenolic glycosides (Sannomiya et al., 1998), 
agar furans (Gonzalez et al., 1993), and a number of phenolic compounds such as flavonoids, xanthones, catechins, leucoanthocyanidins and tannins (Estevam et al., 2009). Some of these compounds are used to treat painful conditions (Mota \& Albuquerque, 2002), while others showed antiseptic, antiasthmatic, antitumoral, and fertility-regulating properties (Lee et al., 1982; Kuo et al., 1990; Ghazanfar, 1994; Gonzalez et al., 1996). The book As Muitas Faces da Jurema (The Many Faces of Jurema) describes the use of the bark of $M$. rigida as a component of "jurema-preta" tea, known for its hallucinogenic properties (Mota \& Albuquerque, 2002) and a previous study showed its antimicrobial activity (Estevam et al., 2009). Since $M$. rigida reportedly have analgesic activities (Mota \& Albuquerque, 2002; Dias et al., 2007), the aim of the present study was better to investigate the antinociceptive (central and peripheral) properties of the ethanol extract of the plant, ethyl acetate fraction, and an isolated compound, using three in vivo mice models, namely, the acetic acid-induced writhing test, the hot plate test, and the formalin-induced nociception test.

\section{Material and methods}

\section{Chemicals}

Analytical and spectroscopic grade solvents were obtained from Grupo Química (Rio de Janeiro, Brazil). Acetic acid, indomethacin, and formaldehyde were supplied by Merck (Darmstadt, Germany). Arabic gum and dypirone were purchased from Sigma (St. Louis, MO, USA), while morphine sulfate (Dimorf) was supplied by Cristália (Itapira, SP, Brazil).

\section{Plant material}

Maytenus rigida Mart., Celastraceae, stem barks were collected as previously described by Dias et al (2007) and a voucher specimen was deposited in the herbarium of the Federal University of Sergipe under reference number 007677. Plant extract preparation, fractioning and (-)-4'methylepigallocatechin (1) isolation were previously described (Dias et al., 2007).

\section{Animals}

Male Swiss mice obtained from breeding units at the Laboratory of Evaluation and Synthesis of Bioactive Substances, Federal University of Rio de Janeiro, Rio de Janeiro, Brazil, and from the Laboratory of Pharmacology and Immunity, Department of Physiology, Federal University of Alagoas, Maceió, Brazil, weighing between 20-30 g each, were used in the antinociceptive tests. The animals were kept at 25$28^{\circ} \mathrm{C}$ under a $12 \mathrm{~h} \mathrm{light/dark} \mathrm{cycle} \mathrm{with} \mathrm{food} \mathrm{and} \mathrm{water}$ provided ad libitum. The study was approved by the Research Ethics Committee of the Federal University of Alagoas (approval protocol UFAL N ${ }^{\circ} 006443 / 2005$ 78 ) and conducted according ethical guidelines for the care of laboratory animals and investigation of experimental pain in conscious animals (Zimmerman, 1983).

\section{Writhing antinociceptive test}

The test was carried out using the method proposed by Koster et al. (1959) with modifications. Mice were randomly divided into groups of 10 to be orally pretreated with the crude ethanol plant extract $(100 \mathrm{mg} / \mathrm{kg})$, ethyl acetate fraction $(100 \mathrm{mg} / \mathrm{kg})$, and compound $1(0.32-96.1 \mathrm{mg} / \mathrm{kg}), 60 \mathrm{~min}$ before the administration of $0.25 \mathrm{~mL}$ of $0.6 \%$ acetic acid by intraperitoneal injection. Positive control groups orally received the standard analgesic dypirone (0.1-100 mg/ $\mathrm{kg}$ ) and the standard anti-inflammatory indomethacin (0.036-107.3 mg/kg), while negative control animals received a dose of the vehicle Arabic gum 5\% (10 $\mathrm{mL} / \mathrm{kg}$ ) before administering acetic acid. The number of abdominal writhes showed by each mouse was counted starting $10 \mathrm{~min}$ after injecting acetic acid, and counting was continued for $20 \mathrm{~min}$. The antinociceptive activity was expressed as the percentage of inhibition of constrictions compared with the negative control group.<smiles>COc1c(O)cc(C2Oc3cc(O)cc(O)c3CC2O)cc1O</smiles>

\section{Hot plate antinociceptive test}

The latency of the response in mice was measured using the hot plate test, which was carried out according to the method of Eddy \& Leimback (1953) with minor modifications. Animals were previously chosen based on the response to heat. Only animals showing a reaction time within the range of 4-10 s were selected for inclusion in the test groups. Animals were placed on the heated surface of an Ugo Basile (Varese, Italy) DS 37 hot plate maintained at $55.5 \pm 1{ }^{\circ} \mathrm{C}$, and latency was measured, which is defined as the time between placement and the first indication of licking of the paws or jumping. Groups of 10 mice were orally pretreated with the vehicle $5 \%$ Arabic gum $(10 \mathrm{~mL} / \mathrm{kg}$, negative control, oral dose), compound 1 (32 mg/kg, 
oral dose) or morphine $(4.25 \mathrm{mg} / \mathrm{kg}$, positive control, i.p.). Treatment latencies were recorded at $0,60,90$, 120 and $150 \mathrm{~min}$.

\section{Formalin-induced pain test}

The formalin test was performed according to the method of Hunskaar \& Hole (1987). Groups of ten mice were orally pretreated with either vehicle 5\% arabic gum (10 mL/kg, negative control), compound $1(32 \mathrm{mg} / \mathrm{kg})$ or indomethacin $(12.9 \mathrm{mg} / \mathrm{kg}$, positive control), and $60 \mathrm{~min}$ later with $2.5 \%$ formaldehyde (20 $\mu \mathrm{L}$ ) injected into the subplantar region of the right hind paw. The time each animal spent licking its paws during the first $5 \mathrm{~min}$ (first phase) and from 15 to $30 \mathrm{~min}$ (second phase) following injection was recorded. The test was performed at $22-26{ }^{\circ} \mathrm{C}$ and care was taken to exclude environmental disturbances (high temperature, noise and excessive movement) that might interfere with the natural response of the animal (Tjølsen et al., 1992).

\section{Data analysis}

Results were recorded as mean values \pm SEM. The significance of differences between mean values was determined by ANOVA and Dunnett's test for $p \leq 0.05$. The ED50 values were determined by linear regression using Graph Pad Prisma ${ }^{\circledR}$ software.

\section{Results}

\section{Writhing test}

The antinociceptive activities of the crude ethanol extract of the stem bark of $M$. rigida, ethyl acetate fraction and $\mathbf{1}$ were initially evaluated using the acetic acid-induced writhing test. Administration of acetic acid by intraperitoneal injection to a negative control group of mice that had been orally pretreated with vehicle (arabic gum) induced $50.5 \pm 5$ contortions during the observation period. On the other hand, in the groups of animals pretreated with ethanol extract and ethyl acetate fraction at $100 \mathrm{mg} / \mathrm{kg}$, and 1 at $32 \mathrm{mg} / \mathrm{kg}$, acetic acid-induced writhing was inhibited by $98.4,84.4$, and $58.3 \%$, respectively, all of which are values that differed significantly from that of the control $(p<0.05$, Figure $1)$. The group of animals that received dypirone as a standard antinociceptive drug presented $56 \%$ of writhing inhibition compared with the control group.

To further evaluate the effects of $\mathbf{1}$ on inflammatory pain, the relationship between the inhibition and doses of 1, dypirone (analgesic) and indomethacin (anti-inflammatory) were determined and are shown in Figure 2. The calculated ED50 for 1 was $14.14 \mathrm{mg} / \mathrm{kg}$, a value that is comparable with those of the reference drugs dypirone and indomethacin (Figure 1). These data demonstrated that $M$. rigida possesses a potent anti-inflammatory effect, and suggest that $\mathbf{1}$ is one of the constituents responsible for this activity. Although no specific test for the toxicity or effect of $\mathbf{1}$ on motor activity was done, it was observed that treated animals did not show any apparent sign of toxicity such as lethargy, decreased motor activity, morbidity, or mortality, when monitored for $72 \mathrm{~h}$ after administration of the extract, fraction, and $\mathbf{1}$.

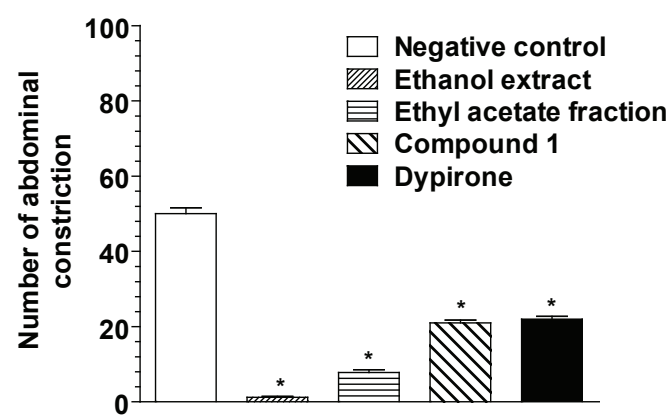

Figure 1. Effect of the oral administration of vehicle $5 \%$ arabic gum $(10 \mathrm{~mL} / \mathrm{kg})$, ethanol extract of Maytenus rigida $(100 \mathrm{mg} / \mathrm{kg})$, ethyl acetate fraction $(100 \mathrm{mg} / \mathrm{kg}),(-)-4^{\prime}-$ methylepigallocatechin $(1,32 \mathrm{mg} / \mathrm{kg})$, and dypirone (11 $\mathrm{mg} / \mathrm{kg}$ ) on acetic acid-induced visceral pain in mice. Each point represents the mean number of abdominal constrictions measured over a 20 minute period $( \pm \mathrm{SEM} ; \mathrm{n}=10)$. Mean values indicated by bars bearing asterisks differ significantly $(p<0.05)$ from that of the negative control.

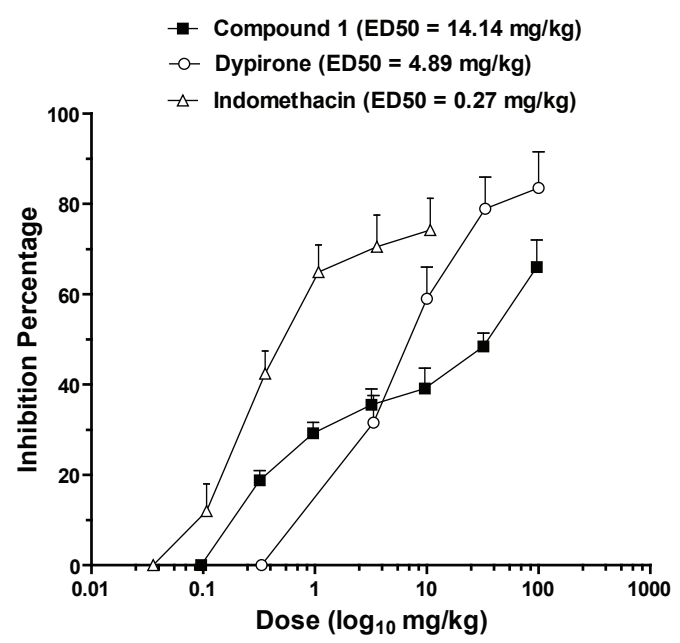

Figure 2. Dose-dependent effect of dypirone (0.100-100 mg/ $\mathrm{kg}),(-)-4$ '-methylepigallocatechin (1, 0.32-96.1 mg/kg), and indomethacin $(0.036-107.3 \mathrm{mg} / \mathrm{kg})$ on acetic acid-induced visceral pain in mice. Each point represents the mean percentage reduction in abdominal constrictions $( \pm \mathrm{SEM} ; \mathrm{n}=10)$. Mean values indicated by bars bearing asterisks differ significantly $(p<0.05)$ from that of the negative control. In some cases error bars are obscured by the plot symbols. 
Hot plate test

To confirm the antinociceptive effect of $\mathbf{1}$, and to find out whether the process is mediated by central or peripheral mechanisms, models to investigate the nociceptive activity were employed. In the hot plate test, mice pretreatment with 1 produced a significant increase $(p<0.05)$ in the latency time between 60 and $150 \mathrm{~min}(60-$ $89 \%$; Figure 3 ). Although the increase in latency induced by 1 following $30 \mathrm{~min}$ of post treatment was smaller than the one produced by morphine (70-161\%), the effects generated by $\mathbf{1}$ and morphine were of similar duration and magnitude at 90,120 and 150 min after pretreatment. These results suggest the antinociceptive of $\mathbf{1}$ is in part mediated by its central analgesic action.

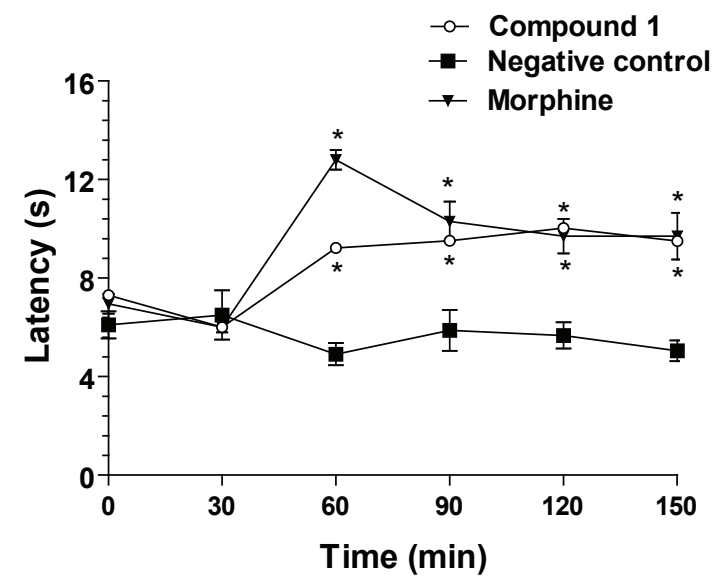

Figure 3. Effect of the administration of vehicle $5 \%$ arabic gum (10 mL/kg, p.o.), (-)-4'-methylepigallocatechin (1, 32 $\mathrm{mg} / \mathrm{kg}$, p.o. $)$, and morphine $(4.25 \mathrm{mgl} / \mathrm{kg}$, i.p. $)$ on latency in mice measured by the hot plate test. Each point represents the mean latency ( \pm SEM; $n=10$ ). Mean values indicated by bars bearing asterisks differ significantly $(p<0.001)$ from that of the negative control. In some cases, error bars are obscured by the plot symbols.

\section{Formalin-induced pain test}

The anti-inflammatory profile of $\mathbf{1}$ was determined using a classic nociception model based on the two phases of the formalin-induced pain test. As shown in Figure 4, oral administration of $\mathbf{1}$ induced significant reductions in the licking activity in both phases compared with the control $(p<0.05)$ by 50 and $26.5 \%$, respectively, while indomethacin had no effect on the first phase, although it promote a $41.2 \%$ reduction in the licking activity in the second phase when compared with the control. These results suggest the antinociceptive activity of $\mathbf{1}$ is mediated by both central and peripheral mechanisms.
A

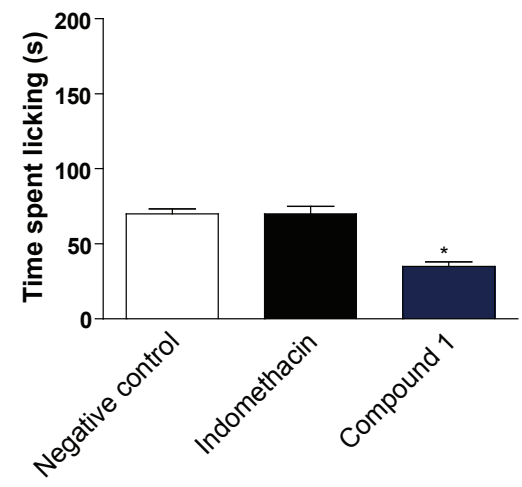

B

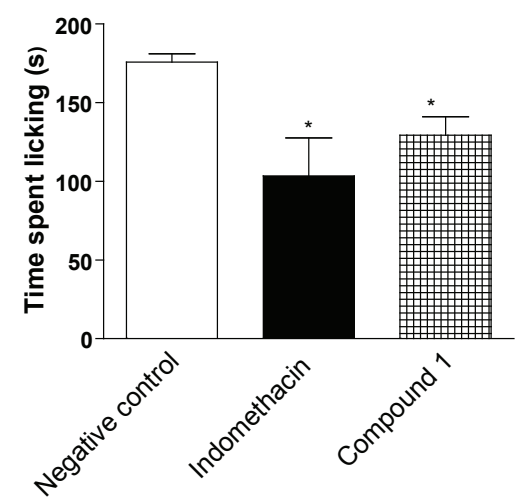

Figure 4. Effect of oral administration of vehicle 5\% arabic gum $(10 \mathrm{~mL} / \mathrm{kg})$, indomethacin $(12.9 \mathrm{mg} / \mathrm{kg})$, and (-)-4'methylepigallocatechin $(\mathbf{1}, 32 \mathrm{mg} / \mathrm{kg})$ on the first phase $(0-5$ min, A) and second phase (15-30 min, B) of formalin-induced nociception in mice. Each point represents the mean time spent licking ( \pm SEM; $n=10$ ). Mean values indicated by bars bearing asterisks differ significantly $(p<0.001)$ from that of the negative control. In some cases, error bars are obscured by the plot symbols.

\section{Discussion}

Although few studies have focused on the antinociceptive activity of plants in the Maytenus genus, a previous report showed antinociceptive effects of the hexane and ethyl acetate extracts of $M$. ilicifolia Mart. ex. Reiss at $320 \mathrm{mg} / \mathrm{kg}$ without any toxicity in mice (Jorge et al., 2004). Analgesic properties of Maytenus rigida Mart., Celastraceae, stem bark were previously investigated using the tail flick test, which showed the spinal antinociceptive potential of the plant extract and its ethyl acetate fractions at $100 \mathrm{mg} / \mathrm{kg}$, which were chosen to be used in the present study, and 1. Although that study did not give extensive information on the action mechanism, it showed the involvement of the opioid receptor in the antinociception (Dias et al., 2007). 
Compound 1 was tested at $32 \mathrm{mg} / \mathrm{kg}$ in the present study, which is smaller than the $75 \mathrm{mg} / \mathrm{kg}$ used by those authors. In the present study, antinociceptive tests were selected so supraspinal antinociception and inflammatory effects could be investigated.

The findings of the present study showed the $M$. rigida stem bark hydroethanol extract, its ethyl acetate fraction and $\mathbf{1}$ obtained from the ethyl acetate fraction (Dias et al., 2007) presented in vivo antinociceptive activity when orally administered to mice. The acetic acid-induced writhing method is widely used to evaluate peripheral antinociceptive activity, which is characterized by inflammation (Gene et al., 1998). The test is very sensitive and is able to detect antinociceptive effects at dosage levels that appear inactive when applied in other methods such as the tail-flick test (Bentley et al., 1981). Local peritoneal receptors are believed to be partly involved in the abdominal constriction response (Bentley et al., 1983), although the acute inflammatory reaction is thought to be related to increased levels of PGE2 and PGF2 $\alpha$, as well as lipooxygenase products in peritoneal fluids (Deraedt et al., 1980). Considering that peripherally acting nonsteroidal drugs, such as dipyrone and indomethacin, inhibit the writhing response in the abdominal constriction model, these compounds were used as standard drugs. Peripheral drugs are cyclooxygenase (COX) inhibitors and show activity in this model (Deraedt et al., 1980; Marchioro et al., 2005). Therefore, it is possible the extract, fraction and $\mathbf{1}$, in mimicking indomethacin, may have a peripherally mediated activity, which may be associated partly with lipooxygenase and/or cyclooxygenase. However, further studies should be conducted to confirm this hypothesis.

(-)-4'-Methylepigallocatechin (1) induced a dose-dependent antinociceptive effect in the aceticacid writhing model. Thus, its antinociceptive activity was further investigated by the hot plate test and in the formalin-induced pain test. The former test is often employed to evaluate narcotic analgesics and other centrally acting drugs and to investigate their supraspinal action. In the present study, 1 mimicked the effects of morphine, which indicated supraspinal antinociceptive effect with central activity. In the formalin model, however, there is a distinctive biphasic nociceptive response in which the first (or neurogenic) phase is associated with the irritating effect of formalin on the sensory fibers of type $\mathrm{C}$, while the second phase represents inflammatory pain in response to the release of serotonin, histamine, bradykinin, and prostaglandins and, at least to some degree, central nociceptive neuron sensitization (Marchioro et al., 2005). Drugs that act primarily on the central nervous system inhibit both phases equally, while peripherally acting drugs inhibit the second phase (Chen et al., 1995; Marchioro et al., 2005). Neurogenic and inflammatory pain suppression, as observed in the present study when $\mathbf{1}$ was administered to mice, strongly indicates the presence of both central and peripheral effects.

\section{Conclusions}

The present study supports the traditional use of $M$. rigida to treat painful and inflammatory conditions. To the best of our knowledge, it is the first report on the in vivo anti-inflammatory effects of the stem bark extract of $M$. rigida, as well as its ethyl acetate fraction. The (-)-4'-methylepigallocatechin (1) isolated of the plant showed antinociceptive activity by inducing both central and peripheral pain relief in mice. Thus, it confirms the pharmacological activities previously described for this species, which include analgesic (Mota \& Albuquerque, 2002; Dias et al., 2007), insecticide, antiseptic, antiasthmatic and antitumor activities (Flores, 1998; Ghazanfar, 1994).

\section{Acknowledgments}

This study was financed by the Brazilian research funding agencies Fundação de Amparo à Pesquisa do Estado de Alagoas, Conselho Nacional de Desenvolvimento Científico e Tecnológico, and Fundação Coordenação de Aperfeiçoamento de Pessoal de Nível Superior

\section{References}

Begossi A, Hanazaki N, Tamashiro JY 2002. Medicinal plants in the Atlantic Forest (Brazil): knowledge, use, and conservation. Human Ecol 30: 281-299.

Bentley GA, Newton SH, Starr J 1981. Evidence for an action of morphine and the encephalin on sensory nerve endings in the mouse peritoneum. Br J Pharmacol 73: 325-332.

Bentley GA, Newton SH, Starr J 1983. Studies on the antinociceptive action of agonist drugs and their interaction with opioid mechanisms. Br J Pharmacol 79: $125-134$.

Chen YF, Tsai HY, Wu TS 1995. Anti-inflammatory and analgesic activity from roots of Angelica pubescens. Planta Med 61: 2-8.

Corsino J, Furlam M, Bolzani VDAS, Pereira AMS, Franca SE 1998. Further sesquiterpene pyridine alkaloids from Maytenus aquifolium. Phytochemistry 49: 2181-2183.

Deraedt R, Jouqney S, Delevallee F, Falhaut M 1980. Release of prostaglandins $\mathrm{E}$ and $\mathrm{F}$ in an algogenic reaction and its inhibition. Eur J Pharmacol 51: 17-24.

Dias KS, Marques MS, Menezes IAC, Santos TC, Silva ABL, Estevam CS, Sant'Ana AEG, Pizza C, Antoniolli AR, Marçal RM 2007. Antinociceptive activity of Maytenus rigida stem bark. Fitoterapia 78: 460-464.

Eddy NB, Leimback D 1953. Synthetic analgesics. II. 
Dithinylbutenyl and diethil-enylbutylamines.

Pharmacol Exp Ther 107: 385-393.

Estevam CS, Cavalcanti AM, Cambuí EV, Araujo Neto V, Leopoldo PTG, Fernandes RPM, Araujo BS, Porfírio Z, Sant'Anna AEG 2009. Perfil fitoquímico e ensaio microbiológico dos extratos da entrecasca de Maytenus rigida Mart. (Celastraceae). Rev Bras Farmacogn 19: 299-303

Fenner R, Betti AH, Mentz LA, Rates SMK 2006. Plantas utilizadas na medicina popular brasileira com potencial atividade antifúngica. Braz J Pharm Sci 42: 375-392.

Flores R, Stefanelo S, Franco ETH, Montovani N 1998. Regeneração "in vitro" de Espinheira-Santa (Maytenus ilicifolia Mart.). Rev Bras Agroc 4: 201-205.

Gene RM, Segura L, Adzet T, Marin E, Inglesias J 1998. Heterotheca inuloides: Anti-inflammatory and analgesic effects. J Ethnopharmacol 60: 157-162.

Ghazanfar AS 1994. Handbook of Arabian medicinal plants. Boca Raton: CRC Press.

Gonzalez AG, Jimenez IA, Ravelo AG, Sazatornil G, Bazzocchi IL 1993. New sesquiterpene with antifeedent activity from Maytenus canariensis (Celastraceae). Tetrahedron 49: 697-702.

Gonzalez AG, Alvarenga NL, Ravelo AG, Jimenez IA, Bazzocchi IL, Canela NJ, Moujir LM 1996. Antibiotic phenol nor-triterpenes from Maytenus canariensis. Phytochemistry 43: 129-132.

Gonzalez AG, Portela TY, Stripp EJ, Di Stas LC 2001. Antiulcerogenic and analgesic effects of Maytenus aquifolium. J Ethnopharmacol 30: 41-47.

Hunskaar S, Hole K 1987. The formalin test in mice: dissociation between inflammatory and non-inflammatory pain. Pain 30: 103-114.

Jorge RM, Leite JPV, Oliveira AB, Tagliati CA 2004. Evaluation of antinociceptive, anti-inflammatory and antiulcerogenic activities of Maytenus ilicifolia. J Ethnopharmacol 94: 93-100.

Koster R, Anderson M, De Beer EJ 1959. Acetic acid for analgesic screening. Proc Fed Am Soc Exp Biol 18: 418-420.

Kuo YH, Chen CH, Kuo LMY, King ML, Wu TS, Haruna M, Lee KH 1990. Antitumor agents, 112. Emarginatine B, a novel potent cytotoxic sesquiterpene pyridine alkaloid from Maytenus emarginata. J Nat Prod 53: 422-428.
Lee KH, Nozaki H, Hall IH, Kasai R, Hirayama T, Suzuki H, Wu RY, Huang HC 1982. Antitumor agents, 60. Maytansine, an antileukemic principle from Maytenus diversifolia. J Nat Prod 45: 509-510.

Lima MRF, Ximenes ECPA, Luna JS, Sant'Ana AEG 2006. The antibiotic activity of some Brazilian medicinal plants. Rev Bras Farmacogn 16: 300-306.

Marchioro M, Blank MFA, Mourão RHV, Antoniolli AR 2005. Anti-nociceptive activity of the aqueous extract of Erythrina velutina leaves. Fitoterapia 76: 637-642.

Mota CN, Albuquerque UP 2002. As Muitas Faces da Jurema de espécie botânica à divindade afro-indígena. Recife: Editora Bagaço.

Reyes CP, Nunez MJ, Jimenez IA, Busserolles J, Alcaraz MJ, Bazzocchi IL 2006. Activity of lupane triterpenoids from Maytenus species as inhibitors of nitric oxide and prostaglandin E(2). Bioorg Med Chem 14: 1573-1579.

Sannomiya M, Vilegas W, Rastrelli L, Pizza C 1998. A flavonoid glycoside from Maytenus aquifolium. Phytochemistry 49: 237-239.

Shirota O, Tamemura T, Morita H, Takeya K, Itokawa H 1996. Triterpenes from Brazilian medicinal plant chuchuhausi (Maytenus krukovii). J Nat Prod 59: 1072-1075.

Sosa S, Morelli CF, Tubaro A, Cairoli P, Speranza G, Manitto P 2007. Anti-inflammatory activity of Maytenus senegalensis root extracts and of maytenoic acid. Phytomedicine 14: 109-114.

Tjølsen A, Berge OG, Hunskaar S, Rosland JN, Hole K 1992. The formalin test: an evaluation of the method. Pain 51: 5-17.

Zimmerman M 1983. Ethical guidelines for investigation of experimental pain in conscious animals. Pain 16: 109110.

\section{*Correspondence}

Charles dos Santos Estevam

Departamento de Fisiologia, Centro de Ciências Biológicas e da Saúde, Universidade Federal de Sergipe, 49100-000, São Cristovão, SE, Brazil

cse@ufs.br

Tel: +55 7921056647

Fax: +558232141384 